\title{
An efficient protocol for the production of transgenic Alstroemeria plants via particle bombardment
}

\author{
Jong Bo Kim \\ Received: 28 March 2020 / Revised: 30 March 2020 / Accepted: 30 March 2020 \\ (c) Korean Society for Plant Biotechnology
}

\begin{abstract}
Alstroemeria plants were transformed by using an improved particle-gun-mediated transformation system. Friable embryogenic callus (FEC) induced from the leaves with axil tissues of Alstroemeria plant was used as the target tissue. Also, FEC was transformed with the bar gene was used as a selectable marker. In the case of plasmid pAHC25, 7.5\% of the twice-bombarded FEC clumps showed blue foci, whereas the clumps with single bombardment showed only $2.3 \%$. Additionally, $\mathrm{a} 90^{\circ}$ rotation with double bombardment led to a higher frequency (6 times) of luciferase gene expression in PBL9780 than the control treatment. After 8 weeks of bombardment, more than 60 independent transgenic lines were obtained for pAHC25 and nearly 150 independent transgenic lines were obtained for PBL9780, all of which were resistant to PPT and demonstrated either GUS or luciferase activity. Regarding effect of osmotic treatment $(0.2 \mathrm{M}$ mannitol) with 7 different periods, the highest transient gene expression was obtained in $8 \mathrm{~h}$ before and $16 \mathrm{~h}$ after transformation in both pAHC25 and PBL9780. Compared with the control, at least three times more GUS foci and photons were observed in this treatment. With respect to different combinations of mannitol and sorbitol with $8 \mathrm{~h}$ before and $16 \mathrm{~h}$ after transformation, high numbers of transient and stable transgene expressions were observed in both $0.2 \mathrm{Mmannitol}$ and $0.2 \mathrm{M}$ sorbitol used in the osmotic pre-culture. This combination showed the highest transformation efficiency in both pAHC25 (8.5\%) and PBL9780 (14.5\%). In the control treatment, only $10 \%$ of the FEC clumps produced somatic embryos. However, by using $0.2 \mathrm{Mmannitol}$ and $0.2 \mathrm{M}$ sorbitol, the frequency of somatic embryos increased to $36.5 \%$ (pAHC25) and 22.9\% (PBL9780). Of the somatic
\end{abstract}

J. B. Kim $(\bowtie)$

Research Institute for Biomedical \& Health Sciences, College of Biomedical \& Health Sciences, Glocal Campus. Konkuk University, Choong-Ju, 27478, Korea

e-mail: jbhee1011@kku.ac.kr embryos produced, at least $60 \%$ germinated. Approximately 100 somatic embryos from these 210 independent transgenic lines from 2 plasmids developed into shoots, which were then transferred to the greenhouse. PCR analysis confirmed the presence of the bar gene. This is the report on the production of transgenic Alstroemeria plants by using particle bombardment with a high efficiency, thereby providing a new alternative for the transferring of gene of interests in Alstroemeria in the breeding program in the future.

Keywords Alstoemeria, Friable embryogenic callus, GUS, Luciferase, Particle Bombardment, Transformation

\section{Introduction}

Alstroemeria is a popular ornamental plant, grown for the cut-flower industry or as indoor potted plants. To introduce the gene of interests into an Alstroemeria breeding program, an efficient and reliable genetic transformation system is required. Genetic transformation systems may provide opportunities to improve other agriculturally important traits, such as resistance to bacterial or fungal diseases or abiotic stresses, in breeding stocks or directly in elite genotypes. Due to these advantages, genetic transformation is regarded as a promising tool in agricultural breeding programs. It may also lead to the simultaneous introduction of multiple genes (Campbell et al. 2004), and thus becoming important in monocot breeding programs for vegetatively propagated ornamentals, such as Alstroemeria, crocus, gladiolus, lily, narcissus, and tulip. In Alstroemeria, although transgenic plants were generated by particle bombardment (Lin et al. 2000) and Agrobacterium (Aktusu et al. 2004a and 2004b; Kim et al. 2007), transformation efficiencies were rather low to apply for the production of transgenic Alstroemeria plants with a high efficiency. Also, production of transgenic Alstroemeria plants via Agrobacterium-mediated transformation 
has limitation to apply for monocot ornamentals since monocot plants are not host in general. However, since Sanford et al. (1987) developed a protocol via particle bombardment, this method has been widely used for the development of transformation systems for dicot and monocot plants. To use particle bombardment method for the production of transgenic Alstroemeria plants, size and volumes of gold particle and the number of shooting are important factors (Morrish et al. 1993). Furthermore, pre-treatment of osmoticum can be influenced on transformation efficiency (Watad et al. 1998) and effects of osmoticum treatments were tested in Corn (Vain et al. 1993), Lily (Kim 2017), Oncidium (Li et al. 2005) and Phalaenopsis (Roh and Kim 2014). Therefore, factors influence on transformation efficiency in particle bombardment should be optimized to develop elite transgenic Alstroemeria plants which can be used for further breeding program.

The objective of this study was to further optimize the particle-gun-mediated transformation system by applying osmotic treatments and re-transformation with two different constructs.

\section{Materials and Methods}

\section{Plant material}

Friable embryogenic callus (FEC) induced from Alstroemeria leaves with axil tissues (VV024, tetraploid cultivar from Van Staaveren B.V, The Netherlands) was used in this experiments. FECs were cultured on PCA medium (Sofiari et al. 1998) at $18^{\circ} \mathrm{C}$ in the dark by refreshing the medium every four weeks. The $\mathrm{pH}$ of the medium was adjusted to 6.0 before autoclaving at $121^{\circ} \mathrm{C}$ and $120 \mathrm{kPa}$ for $15 \mathrm{~min}$ unless stated otherwise. FECs were selected to perform particle bombardment. Unless otherwise stated, 6-month-old FECs were bombarded in all the experiments.

\section{Plasmid construction}

For the optimal particle bombardment and co-transformation results, plasmids pAHC25 and PBL9780 were used. Plasmid pAHC25 (Christensen and Quail 1996) contained the uidA and bar genes, coding for b-glucuronidase (GUS) and resistance to phosphinothricin (PPT), respectively, under the control of the maize ubiquitin promoter. Plasmid PBL9780 contained the luc gene, coding for luciferase, in addition to the bar gene and was constructed by ligating plasmids
pAHC18 and pAHC25 (Christensen and Quail 1996) to each other after digesting them with AatIII and SstI.

DNA coating and particle bombardment

The Promega Wizard Midiprep DNA purification kit was used to isolate plasmid DNA. The final DNA concentration was set to $1.1 \mathrm{mg} / \mathrm{ml}$ in sterilized distilled water. Plasmid DNA $(25 \mu \mathrm{g})$ was then mixed with $15 \mathrm{mg}$ gold particles (size $1.6 \mathrm{~mm}$ ) in an Eppendorf tube by vortexing for $1 \mathrm{~min}$ and centrifuged at $11,000 \mathrm{rpm}$ for $10 \mathrm{~s}$. The following ingredients were then individually added: $30 \mathrm{ml} 5 \mathrm{M} \mathrm{NaCl}, 5 \mathrm{ml}$ $2 \mathrm{M}$ Tris- $\mathrm{HCl}$ (pH 8.0), $100 \mathrm{ml} 0.1 \mathrm{M}$ spermidine, $100 \mathrm{ml}$ 25\% PEG1550, $100 \mathrm{ml} 2.5 \mathrm{M} \mathrm{CaCl}_{2}$, and $965 \mathrm{ml}$ sterile double-distilled water. After re-centrifugation, the coated gold particles in the pellet were washed with $1 \mathrm{ml}$ sterilized water, centrifuged again, and resuspended with $10 \mathrm{ml} 100 \%$ ethanol. Finally, $163 \mathrm{ml}$ of this suspension of DNA-coated gold particles was pipetted onto a macrocarrier (BioRad, California, USA) and used for bombardment.

For each bombardment, approximately $200 \mathrm{mg}$ of FEC clumps grown on PCA medium was evenly spread in a circle with a $2.5 \mathrm{~cm}$ diameter at the center of a Petri dish $(60 \times 15 \mathrm{~mm})$ containing PCA medium. The dishes were placed in a vacuum chamber of a Biolistic Delivery System (PDS-1000/He, BioRad, California, USA), $5 \mathrm{~cm}$ away from the stopping plate. The helium pressure was set at 1350 PSI with a partial vacuum of 28 inch $\mathrm{Hg}$. After the FEC clumps were bombarded, they were transferred to a selection medium (SM) consisting of Murashige and Skoog (1962) basal salts with vitamins, $0.5 \mathrm{mg} / 1 \mathrm{BA}, 30 \mathrm{~g} / \mathrm{l}$ sucrose, 2.75 $\mathrm{g} / \mathrm{l}$ Gelrite ( $\mathrm{pH} 6.0$ ), and $20 \mathrm{mg} / \mathrm{l} \mathrm{PPT}$.

Optimization of particle bombardment

The particle bombardment procedure was optimized by using plasmids pAHC25 and PBL9780. First, the effects of different shooting positions on transformation efficiency and transient luc/gus gene expression levels were evaluated. Tissues were bombarded either once, or twice with the Petri dish rotated $90^{\circ}$ after the first bombardment. Next, to determine the transformation efficiency and transient gene expression levels, luciferase and GUS assays were performed 4 weeks after bombardment. Data on the number of transgenic lines derived per $100 \mathrm{mg}$ of FEC were recorded 8 weeks after transformation.

Next, the effect of osmotic treatment on the gene expression levels was tested. Bombarded FEC cultures were transferred to SM supplemented with $0.2 \mathrm{M}$ mannitol under either of the following culture regimes: A) osmoticum $4 \mathrm{~h}$ 
before and $8 \mathrm{~h}$ after transformation, B) osmoticum only $4 \mathrm{~h}$ before, C) osmoticum only $8 \mathrm{~h}$ after, D) osmoticum $8 \mathrm{~h}$ before and $16 \mathrm{~h}$ after, E) osmoticum only $8 \mathrm{~h}$ before, F) osmoticum only $16 \mathrm{~h}$ after, and $\mathrm{G})$ no osmoticum (Control) in the SM. Gene expression levels were measured 2 and 8 weeks after bombardment.

In another set of experiments, different osmotic treatments were compared as follows: medium I containing $0.2 \mathrm{M}$ mannitol, medium II containing $0.2 \mathrm{M}$ sorbitol, and medium III containing $0.2 \mathrm{M}$ mannitol and $0.2 \mathrm{M}$ sorbitol. FEC cultures were transferred to either of the media indicated above, cultured for $8 \mathrm{~h}$, and then bombarded. A replica of this set was cultured for another $8 \mathrm{~h}$ and then bombarded for the second time. For this experiment, randomly selected FEC clumps (ca $1 \sim 1.5 \mathrm{~mm}$ in diameter) were placed on SM medium before they were treated as above. For each treatment, five Petri dishes $(90 \times 15 \mathrm{~mm}$, Greiner) of FEC clumps $(\mathrm{n}=96$ per dish) were bombarded.

\section{GUS assay}

GUS gene expression levels were evaluated by incubating the samples for $16 \mathrm{~h}$ at $37^{\circ} \mathrm{C}$ in 5-bromo-4-chloro-3-indoylD-glucuronic acid (X-Gluc) solution containing $10 \mathrm{mM}$ EDTA and $0.1 \%$ Triton X-100. This assay was performed at days 7, 14, 30, and 50 after bombardment.

\section{Luciferase assay}

Bombarded FECs and somatic embryos were assayed 7, 14,30 , and 50 days after bombardment. To evaluate the expression levels of the luciferase gene, FECs and somatic embryos were sprayed with $0.15 \mathrm{mg} / \mathrm{l}$ of luciferin aqueous solution, placed in a dark room, and exposed to a luminometer equipped with a CCD camera (Hamamatsu, Japan) that was linked to a personal computer. The amount of light generated by the transformed tissues was automatically recorded. After each measurement, the FECs and somatic embryos were transferred to fresh medium for further growth and development.

Selection and regeneration of bombarded FECs and somatic embryos by screening for the gus/luc activity and using PPT as a selection marker

For pAHC25 transformation, immediately after bombardment, FECs and somatic embryos were placed on SM as described before. They were assayed for GUS activity at days $4 \sim 5$, $15,21,50$, and 100 after bombardment.
For PBL9780 transformation, immediately after bombardment, bombarded tissues were transferred to SM supplemented with MS basal salts with vitamins, $0.5 \mathrm{mg} / 1$ BA, $30 \mathrm{~g} / 1$ sucrose, $2.75 \mathrm{~g} / \mathrm{l}$ Gelrite (pH 6.0), and $20 \mathrm{mg} / \mathrm{l}$ PPT. One week after the bombardment, the bombarded tissues were screened for luciferase activity. Luciferasepositive clumps were picked and transferred to fresh SM for further growth. This procedure was repeated at days 15, 21, 50, and 100 after bombardment. Transformation efficiency (\%) was measured by dividing the number of luciferase-positive clumps with the total number of bombarded tissues. A luciferase-positive clump obtained four weeks after the transformation was regarded as an individual line and transferred to SM for regeneration. All transgenic lines were provided with fresh medium every four weeks unless stated otherwise.

During the selection process, the PPT concentration in SM varied. During the first subculture, gus- or luc-positive transgenic lines were placed on SM containing $20 \mathrm{mg} / \mathrm{l}$ PPT one week after bombardment. In the first and second rounds of subculture, vigorously growing light yellow FECs were selected and transferred to fresh SM. During the third and fourth rounds of subculture, the concentration of PPT was decreased to $10 \mathrm{mg} / \mathrm{l}$. By this time, most of the non-resistant clumps had died. In the final round (sixth) of subculture approximately $5 \sim 6$ months after the bombardment, surviving clumps, which were still gus/luciferase positive, were transferred to SM without PPT. These clumps developed into plantlets within $4 \sim 6$ weeks.

\section{Molecular characterization of regenerated transgenic lines}

PCR analysis was conducted to demonstrate the presence of the bar gene in the transformed plants. Genomic plant DNA was extracted from $250 \mathrm{mg}$ of the regenerated putative transgenic lines, as described by Lin et al (2000). These DNA samples ( $2 \mathrm{mg}$ each) were analyzed by PCR. The forward and reverse primer sequences used for detecting the bar gene (244 bp) were 5'-CGCAGGAACCGCAGGA GTGGAC-3' and 5'-CTCTTGAAGCCCTGTGCCTCCA-3', respectively. Reactions were carried out using $30 \mathrm{pmol}$ of each primer, $300 \mathrm{mM} \mathrm{dNTP}, 0.25 \mathrm{u}$ Taq polymerase in 50 $\mathrm{mM} \mathrm{KCl}, 1.5 \mathrm{mM} \mathrm{MgCl}_{2}$, and $10 \mathrm{mM}$ Tris- $\mathrm{HCl}, \mathrm{pH} 7.3$. The PCR program was $94^{\circ} \mathrm{C}$ initial melting for $5 \mathrm{~min}$, followed by 35 cycles of $94^{\circ} \mathrm{C}$ for $30 \mathrm{~s}, 51^{\circ} \mathrm{C}$ for $30 \mathrm{~s}$, and $72^{\circ} \mathrm{C}$ for $30 \mathrm{~s}$. The final extension step was performed at $72^{\circ} \mathrm{C}$ for $7 \mathrm{~min}$. 


\section{Statistical analysis}

The data are presented as mean \pm standard error (SE) and were analyzed using the least significant difference (LSD) test $(P=0.05)$ for multiple comparisons (SPSS for Windows version $10.0^{\prime}$ statistical software).

\section{Results}

Optimization of particle bombardment

In the first experiment, FEC samples were bombarded once or twice with either pAHC25 or PBL9780. The results of the single bombardment were compared with those of the double bombardment. The distance to objects $(5.5 \mathrm{~cm})$, the helium pressure $(25 \mathrm{Hg})$, and the gas pressure of the microcarrier $(1,350 \mathrm{psi})$ were set according to the procedures described by Lin et al. (2000). Transient luciferase and GUS expression were detected at high levels (Figs. 1A and B). Regarding plasmid pAHC25, 7.5\% of the doublebombarded FEC clumps showed blue foci, whereas only $2.3 \%$ of the clumps bombarded once had this phenotype (Table 1). Additionally, double bombardment with PBL9780 led to a higher frequency (6 times) of luciferase-positive clumps than that of the control treatment. After 8 weeks of bombardment, more than 60 independent transgenic lines were obtained for pAHC25, and nearly 150 independent transgenic lines were obtained for PBL9780, all of which were resistant to PPT (Fig. 1C) and demonstrated either GUS or luciferase activity.

In the second experiment, FECs were cultured with osmotic treatment $(0.2 \mathrm{M}$ mannitol) for seven different periods. The highest transient gene expression levels for both pAHC25 and PBL9780 were obtained in regime D ( $8 \mathrm{~h}$ before and $16 \mathrm{~h}$ after transformation) (Fig. 2). Compared with the control values, $\geq 3$ times more GUS foci and photons were observed in regime $\mathrm{D}$.

In the next experiment, bombarded FECs were cultured in SM medium with three different osmotic treatments (A:
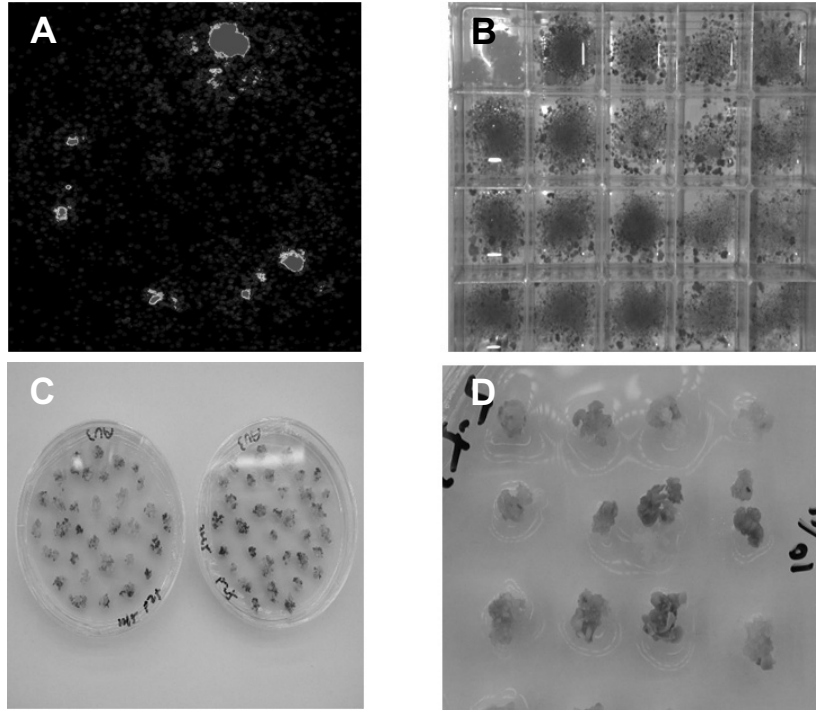

Fig. 1 Transient gene expression of luciferase and GUS gene in transgenic Alstroemeria

A) luciferase expression of FEC clumps 1 week after transformation (red: high expression, blue: low expression)

B) GUS gene expression of FEC clumps 2 weeks after transformation

C) PPT-resistant FEC clumps 6 weeks after transformation

D) germination of transgenic somatic embryos 14 weeks after transformation using the stringent PPT selection

0.2 M mannitol, B: $0.2 \mathrm{M}$ sorbitol, and C: $0.2 \mathrm{M}$ mannitol and $0.2 \mathrm{M}$ sorbitol) for $8 \mathrm{~h}$ before and $16 \mathrm{~h}$ after the bombardment. These conditions were then compared with the control. High levels of transient or stable transgene expression were observed for treatment $\mathrm{C}$ (Table 2).

According to these results, the combination of mannitol and sorbitol resulted in the highest transformation efficiency for both pAHC25 (8.5\%) and PBL9780 (14.5\%). This osmotic treatment led to less browning than those observed with the other treatments and had a positive effect on the recovery of the transgenic lines. In the control, only $10 \%$ of the FEC clumps produced somatic embryos. However, by using $0.2 \mathrm{M}$ mannitol and $0.2 \mathrm{M}$ sorbitol, the frequency of somatic embryos increased to $36.5 \%$ (pAHC25) and $22.9 \%$ (PBL9780). Of the somatic embryos produced, at least $60 \%$ germinated (Fig. 1D). PCR analysis was per-

Table 1 Effect of shooting position and time on transient gene expression

\begin{tabular}{ccccc}
\hline \multirow{2}{*}{ Plasmids } & $\%$ of luc or gus/ PPT positive FEC clumps ${ }^{\mathrm{a}}$ & \# of transgenic lines / $100 \mathrm{mg}^{\mathrm{FEC}}$ \\
\cline { 2 - 5 } & Control & 90 degree rotation & Control & 90 degree rotation \\
\hline PAHC25 & $2.3 \pm 0.2 \mathrm{a}^{\mathrm{c}}$ & $7.5 \pm 1.1 \mathrm{~b}$ & $37.5 \pm 7.5 \mathrm{a}$ & $64.5 \pm 8.6 \mathrm{~b}$ \\
PBL9780 & $1.5 \pm 0.1 \mathrm{a}$ & $9.4 \pm 2.4 \mathrm{~b}$ & $48.5 \pm 2.2 \mathrm{a}$ & $147.5 \pm 15.9 \mathrm{~b}$ \\
\hline
\end{tabular}

${ }^{\mathrm{a}}$ Data was measured 4 weeks after transformation

${ }^{\mathrm{b}}$ Data was measured 8 weeks after transformation

${ }^{\mathrm{c}}$ Means followed by different letters are significantly different at the $\mathrm{P}=0.05$ level. 

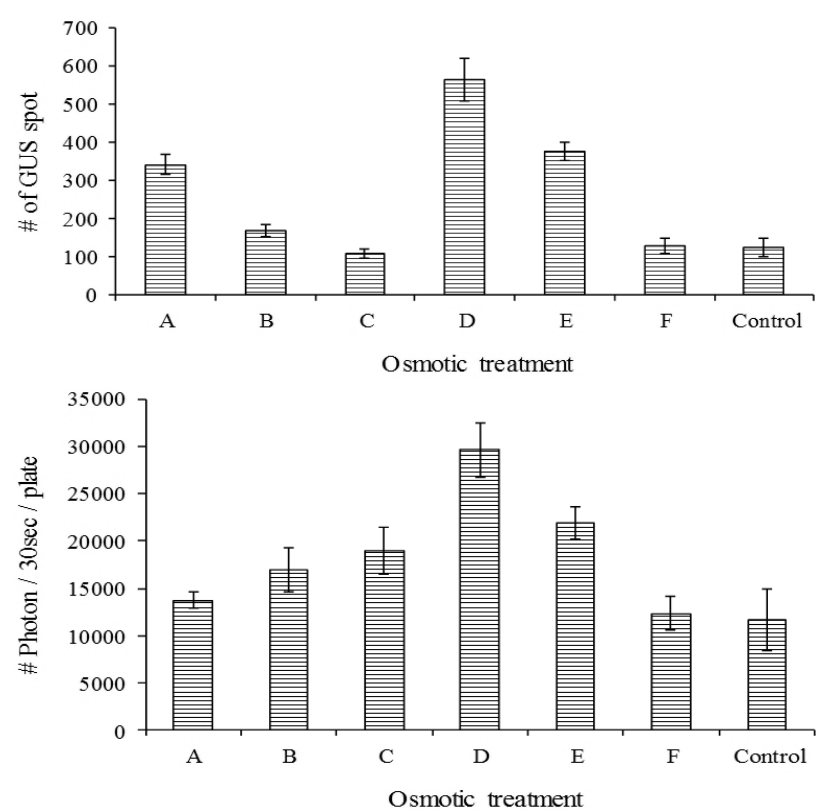

Fig. 2 Effect of different culturing regimes with osmoticum. (A: $4 \mathrm{~h}$ before and $8 \mathrm{~h}$ after; B: $4 \mathrm{~h}$ before; C: $8 \mathrm{~h}$ after; D: $8 \mathrm{~h}$ before and $16 \mathrm{~h}$ after; E: $8 \mathrm{~h}$ before; F: $16 \mathrm{~h}$ after; Control: no osmotic treatment)

formed to determine the presence of the selectable marker bar gene (Fig. 3: the bar gene). Transgenic plants that yielded amplicons with the expected sizes were considered PCR-positive.

\section{Discussion}

Although conventional breeding has highly contributed to ornamental breeding, there is still a demand for genetic

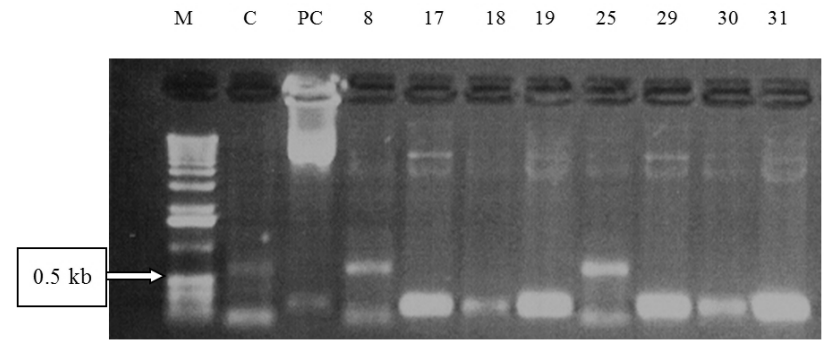

Fig. 3 PCR analysis of the transgenes (bar gene, 244 bp) in the transformed Alstroemeria plants (black arrows indicate the corresponding band, and white arrow indicate the size of marker). M: Marker, C: Control (non-transformed Alstroemeria plant), PC: Positive control (pAHC25),

Transgenic lines $(8,17,18,19,25,29,30,31)$

transformation techniques to alter individual traits in many ornamental crops. The success of genetic modification is influenced by several factors, such as available promoter and gene cassettes for proper gene expression, explant source, gene transfer method, selection procedure, and regeneration capacity (Hiei et al. 1997; Smith and Hood 1995). Since Sanford et al. (1987) have developed the particle bombardment technique, successful transformations via a particle gun have been carried out in cymbidium (Yang et al. 1999), gladiolus (Kamo et al. 2000), lily (Watad et al. 1998; Kim 2017), sugarcane (Butterfield et al. 2002), and tulip (Wilmink et al. 1992).

The effect of re-transformation after rotating the Petri dish by $90^{\circ}$ and the effect of osmotic treatment were critical in optimizing the transformation of Alstroemeria. Firstly, a second bombardment, during which the position of the Petri dish was changed by $90^{\circ}$, increased the transformation efficiency. This re-transformation requires fewer explants

Table 2 Effect of osmotic treatments on transient gene expression and recovery of transgenic lines

\begin{tabular}{cccccc}
\hline \multirow{2}{*}{ Plasmids } & Treatment $^{\mathrm{a}}$ & $\begin{array}{c}\text { \% of PPT } \\
\text { positive FEC }\end{array}$ & $\begin{array}{c}\text { \% of } \text { ouc }^{+} / \text {gus }^{+} \\
\text {FEC }^{\mathrm{b}}\end{array}$ & $\begin{array}{c}\text { \% of } \\
\text { browning }^{\mathrm{c}}\end{array}$ & $\begin{array}{c}\text { \# of somatic embryos / } \\
100 \text { FEC clumps }\end{array}$ \\
\hline PAHC25 & A & $23.5 \pm 1.7 \mathrm{c}^{\mathrm{d}}$ & $3.1 \pm 0.2 \mathrm{~b}$ & $2.5 \pm 0.6 \mathrm{~b}$ & $13.5 \pm 0.5 \mathrm{~b}$ \\
& B & $31.4 \pm 1.3 \mathrm{~b}$ & $2.6 \pm 0.4 \mathrm{~b}$ & $3.3 \pm 0.7 \mathrm{~b}$ & $14.4 \pm 4.1 \mathrm{~b}$ \\
& $\mathrm{C}$ & $43.4 \pm 4.7 \mathrm{a}$ & $8.5 \pm 1.7 \mathrm{a}$ & $1.2 \pm 0.1 \mathrm{~b}$ & $36.5 \pm 3.6 \mathrm{a}$ \\
PBL9780 & Control & $26.5 \pm 1.1 \mathrm{c}$ & $3.5 \pm 0.3 \mathrm{~b}$ & $10.1 \pm 0.6 \mathrm{a}$ & $11.4 \pm 2.1 \mathrm{~b}$ \\
& A & $18.5 \pm 3.3 \mathrm{a}$ & $5.5 \pm 1.6 \mathrm{c}$ & $2.2 \pm 0.1 \mathrm{~b}$ & $12.2 \pm 3.5 \mathrm{c}$ \\
& B & $22.6 \pm 4.9 \mathrm{a}$ & $6.4 \pm 0.1 \mathrm{~b}$ & $5.3 \pm 0.9 \mathrm{a}$ & $15.6 \pm 2.8 \mathrm{~b}$ \\
& C & $26.9 \pm 3.2 \mathrm{a}$ & $14.5 \pm 1.5 \mathrm{a}$ & $1.5 \pm 0.1 \mathrm{~b}$ & $22.9 \pm 6.2 \mathrm{a}$ \\
& Control & $19.4 \pm 2.2 \mathrm{a}$ & $4.2 \pm 0.4 \mathrm{c}$ & $8.5 \pm 2.8 \mathrm{a}$ & $9.5 \pm 2.4 \mathrm{c}$ \\
\hline
\end{tabular}

${ }^{\mathrm{a}}$ Treatment A (0.2 M mannitol), B (0.2M sorbitol), C (0.2M mannitol + 0.2M sorbitol), control (no osmoticum)

${ }^{\mathrm{b}}$ Data was measured 6 (PPT) and 8 weeks (LUC/GUS assay) after transformation by counting the number of positive clumps

${ }^{\mathrm{c}}$ Data was measured 12 weeks after transformation by counting the number of tissues with browning and somatic embryos, respectively.

${ }^{\mathrm{d}}$ Means followed by different letters are significantly different at the $\mathrm{P}=0.05$ level. 
for bombardment. When 100-mg FEC was bombarded with pAHC25 plasmid by using this "rotating" method, $>100$ transgenic lines with stable gene expression were derived 6 weeks after transformation. This efficiency is higher than that of the transformation system presently available for Alstroemeria.

Secondly, although osmotic treatment has been reported to impair transient gene expression in broccoli (Puddephat et al. 1999), such treatments had a positive effect on transient gene expression in Alstroemeria. In sugarcane, pre-incubation of calli on a medium supplemented with $0.2 \mathrm{M}$ mannitol and $0.2 \mathrm{M}$ sorbitol for $4 \mathrm{~h}$ enhances transformation (Bower et al. 1996). Similar results have been observed in peach (Ye at al. 1994), tobacco (Russel et al. 1992), maize (Frame et al. 2000) and tall fescue (Gao et al 2008). These observations might be because osmotic treatment presumably plasmolyzes the cells before bombardment (Vain et al. 1993) and thereby decreasing the turgor pressure and preventing plant cells from bursting (Frame et al. 2000). Osmotic treatments also stabilize cell membranes to enhance the recovery of lesions produced by the particle bombardment process (Russel et al. 1992). Additionally, pre-treating FEC cultures with osmoticum ( $8 \mathrm{~h}$, in this study) is thought to initiate the plasmolysis of the plant cells so that fewer cells are damaged during particle bombardment (Vain et al. 1993). The less browning in our FEC cultures indicated that there was less damage to the bombarded tissues than that in the control, as previously observed in triticale (Zimny et al. 1995). Moreover, a higher stable-transformation frequency was observed, as described by Brettschneider et al (1997). Therefore, osmotic treatment is needed to enhance the efficiency of the particle-bombardment-mediated transformation efficiency and the ensuing stable transgene expression in Alstroemeria. We conclude that the concurrent use of both sorbitol and mannitol in this transformation system improves the transgene expression in Alstroemeria FEC cultures or cell clusters.

In summary, a particle bombardment protocol for Alstroemeria was optimized by re-transformation and osmoticum treatments.

\section{Acknowledgement}

The author wish to thank Van Staaveren B.V. (The Netherlands) for kindly providing VV024 Alstroemeria plants. I also thank Bert Essenstam (Unifarm) and Dirkjan Huigen (Plant Breeding, Wageningen University) for taking care of the plants. This research was supported by grants from the Ministry of Education, Republic of Korea, and the Laboratory of Plant Breeding, Wageningen University.

\section{References}

Akutsu M, Ishizaki T, Sato H (2004a) Transformation of the monocotyledonous Alstroemeria by Agrobacterium tumefaciens. Plant Cell Rep 22:561-568

Akutsu M, Ishizaki T, Sato H (2004b) Transformation of the monocot Alstroemeria by Agrobacterium rhizogenes. Mol Breed 13:69-78

Bower R, Elliot AR, Potier BAM, Birch RG (1996) Highefficiency, microprojectile-mediated co-transformation of sugarcane, using visible or selectable markers. Mol Breed 2: 239-249

Brettschneider R, Becker D, Lorz H(1997) Efficient transformation of scutellar tissue of immature maize embryos. Theo Appl Genet 94:737-748

Butterfield MK, Irvine JE, Valdez Garza M, Mirkov TE (2002) Inheritance and segregation of virus and herbicide resistance transgenes in sugarcane. Theo Appl Genet 104:797-803

Campbell MA, Fitzgerald HA, Ronald PC (2004) Handbook of Plant Biotechnology. John Wiley \& Sons Ltd. pp 395-411

Christensen AH, Quail PH (1996) Ubiquitine promoter-based vectors for high-level expression of selectable and/or screenable marker genes in monocotyledonous plants. Transgenic Res 5: 213-218

Frame BR, Zhang H, Cocciolone SM, Sidorenko LV, Dietrich CR, Pegg SE, Zhen S, Schnable PS, Wang K (2000) Production of transgenic maize from bombarded type II callus: effect of gold particle size and callus morphology on transformation efficiency. In Vitro Cell Dev Biol-Plant 36:21-29

Gao G, Long D, Lenk I, Nielsen KK (2008) Comparative analysis of transgenic tall fescue (Festuca arundinacea Schreb.) plants obtained by Agrobacterium-mediated transformation and particle bombardment. Plant Cell Rep 27:1601-1609

Hiei Y, Komari T, Kubo T (1997) Transformation of rice mediated by Agrobacterium tumefaciens. Plant Mol Biol 35:205-218

Kamo K, Blowers A, McElroy D (2000) Effect of the cauliflower mosaic virus $35 \mathrm{~S}$, actin, and ubiquitin promoters on uid $\mathrm{A}$ expression a bar-uidA fusion gene in Gladiolus plants. In Vitro Cell Dev Biol-Plant 36:13-20

Kim JB, Raemakers CJJM, Jacobsen E, Visser RGF (2007) Efficient production of transgenic Alstroemeria plants by using Agrobacterium tumefaciens. Ann Appl Biol 151: 401-412

Kim JB (2017) Optimization of a protocol for the production of transgenic lily plants via particle bombardment. J of Plant Biotechnol 44:82-88

Li SH, Kuoh CS, Chen YH, Chen HH, Chen WH (2005) Osmotic sucrose enhancement of single-cell embryogenesis and transformation efficiency in Oncidium. Plant Cell Tiss Organ Cult 81:183-192 
Lin HS, Van der Toorn C, Raemakers CJJM, Visser RGF, De Jeu MJ and Jacobsen E (2000) Genetic transformation of Alstroemeria using particle bombardment. Mol Breed 6: 369-377

Morrish F, Songstad DD, Armstrong CL, Fromm M (1993) Micro-projectile bombardment: a method for the production of transgenic cereal crop plants and the functional analysis of genes. In: Hiatt A (ed), Transgenic plants: fundamentals and applications. Marcel Dekker, New York, pp 131-171

Murashige T and Skoog F (1962) A revised medium for rapid growth and bioassays with tobacco tissue cultures. Physiol Planta 15:473-497

Puddephat IJ, Thompson N, Robinson HT, Sandhu P, Henderson J (1999) Biolistic transformation of broccoli (Brassica oleracea var. italica) for transient expression of the b-glucuronidase gene. J of Hort Sci \& Biotech 74:714-720

Roh HS and Kim JB (2014) Effects of osmoticum treatments and shooting chances on the improvement of particle gun-mediated transformation in Phalaenopsis. J Plant Biotechnol 41:216-222

Russell JA, Roy MK, Sanford JC (1992) Major improvements in biolistic transformation of suspension-cultured tobacco cells. In Vitro Cell Dev Biol-Plant 28:97-105

Sanford JC, Klein TM, Wolf ED, and Allen N (1987) Delivery of substances into cells and tissues using a particle bombardment process. J of Parti Sci and Tech 6:559-563
Smith RH and Hood EE (1995) Agrobacterium tumefaciens transformation of monocotyledons. Crop Sci 35:301-309

Sofiari E, Raemakers CJJM, Bergervoet JEM, Jacobsen E, Visser RGF (1998) Plant regeneration from protoplasts isolated from friable embryogenic callus of cassava. Plant Cell Rep 18:159-165

Vain P, McMullen MD, Finer JJ (1993) Osmotic treatment enhances particle bombardment-mediated transient and stable transformation of maize. Plant Cell Rep 12:84-88

Watad AA, Yun DJ, Matsumoto T, Niu X, Wu Y, Kononowicz AK, Bressan RA, Hasegawa PM (1998) Microprojectile bombardment-mediated transformation of Lilium longiflorum. Plant Cell Rep 17:262-267

Wilmink A, Van de ven BCE, Dons JJM (1992) Expression of the GUS gene in the monocot tulip after introduction by particle bombardment and Agrobacterium. Plant Cell Rep 11:76-80

Yang J, Lee HJ, Shin DH, Oh SK, Seon JH, Paek KY, Han KH (1999) Genetic transformation of Cymbidium orchid by particle bombardment. Plant Cell Rep 18:978-984

Ye X, Brown SK, Scorza R, Cordts J, Sanford JC (1994) Genetic transformation of peach tissues by particle bombardment. J of Ameri Soc for Hort Sci 119:367-373

Zimny J, Becker D, Brettschneider R, Lorz H (1995) Fertile, transgenic Triticale (' Triticosecale Wittmack). Mol Breed 1: 155-164 